
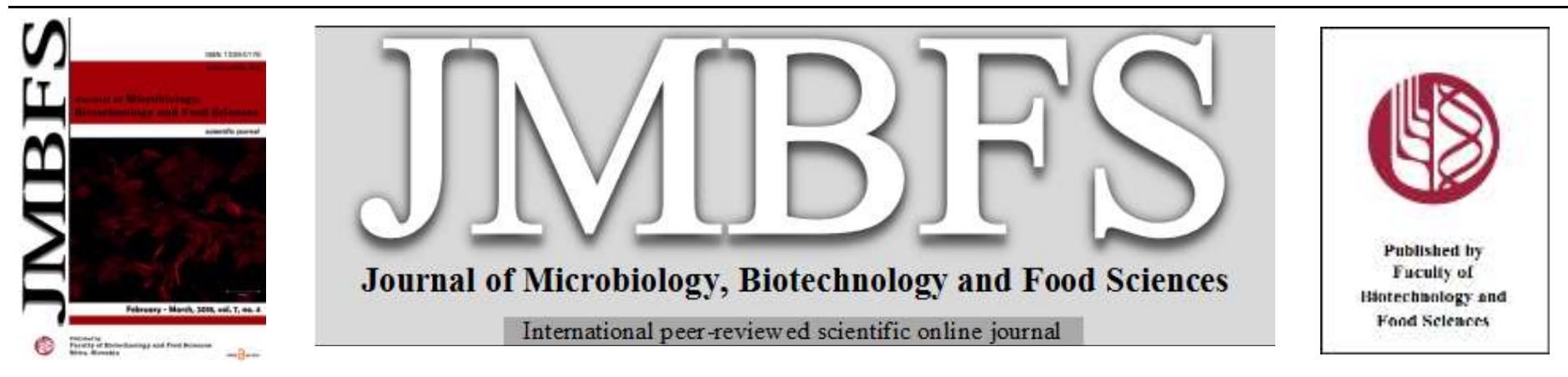

\title{
ACTINOBACTERIA ISOLATED FROM MINERAL ORES IN PERU
}

\section{Jasmin Hurtado *' ${ }^{\text {, Sara Liz Pacheco }}{ }^{1}$, Patricia Sheen ${ }^{2}$ and Daniel Ugarte ${ }^{1}$}

Address(es): Jasmin Hurtado,

${ }^{1}$ Universidad Peruana Cayetano Heredia, Facultad de Ciencias y Filosofía, Laboratorio de Biotecnología Ambiental, Av. Honorio Delgado 430, Lima 31, Lima, Perú, (511) 319-0000.

${ }^{2}$ Universidad Peruana Cayetano Heredia, Facultad de Ciencias y Filosofía, Laboratorio de Biología Molecular y Bioinformática, Av. Honorio Delgado 430, Lima 31, Lima, Perú, (511) 319-0000.

*Corresponding author: jasmin.hurtado@upch.pe

doi: $10.15414 / j m b f s .2018 .7 .4 .366-370$

ARTICLE INFO

Received 13.10. 2017

Revised 6.11. 2017

Accepted 20. 12. 2017

Published 1. 2. 2018

$\overline{\frac{\text { Regular article }}{\operatorname{oren}_{\text {acctss }}}}$

\begin{abstract}
A total of twenty-four isolates of actinobacteria from arsenopyrite, pyrite, polymetallic sulfides and magnetite from Peruvian mining zones have been used with the purpose of characterizing them by morphological, physiological and molecular studies for future biotechnological applications. 23 strains were identified as Streptomyces and1 as Actinomadura sp.95\% and 70\% of the strains were able to grow at $\mathrm{pH} 3.5$ and $\mathrm{pH} 2$, respectively. Only $19 \%$ of them were able to oxidize iron at $\mathrm{pH} 2$. Also, they have been tested by growth on arsenopyrite tailings and Streptomyces sp. E1 and Streptomycesvariabilis AB5 leached $19.1 \%$ and $15.5 \%$ of arsenic, respectively, while the control without inoculum only showed $2.5 \%$ of leaching. Results indicate that these strains show important characteristics for leaching processes.
\end{abstract}

Keywords: Streptomyces, Actinomadura, minerals, bacterial leaching, arsenopyrite

\section{INTRODUCTION}

There is a wide diversity of microorganisms developing on mineral ores, concentrates and tailings. The microbial composition in these environments has been studied based on cultures, as well as sequencing of 16SrRNA (Schippers $\boldsymbol{e t}$ al., 2010). In metagenomic studies of mineral piles, bacteria have predominated against archaea and eukaryotes (Ding et al., 2009; Mendez et al., 2008; Urbietaet al., 2012). In all reports of microbiological studies based on 16SrRNA, the presence of phylum Actinobacteria (Ding et al., 2009; Korechiet al., 2014; Mendezet al., 2008) has been determined, which include the order Acidimicrobiales that has 5 validated genera and a candidate genus "Acidithiomicrobium" (Jones and Johnson, 2015). The 5 genera have a single species: Acidimicrobium ferrooxidans, Aciditerrimonas ferrireducens, Ferrimicrobium acidiphilum, Acidithrix ferrooxidans, Ferrithrix termotolerans (Jones and Johnson, 2015), which have been reported in many parts of the world relating them to biohydrometallurgical processes (Brierley and Brierley, 2013; Schippers et al., 2014). Also, the composition of acidic waters (BacelarNicolau and Johnson, 1999) and sediments from water from mining activity (Blötheet al., 2008; Sanchez-Andrea et al., 2011) have been evaluated and the presence of sequences of Actinobacteria and sequences belonging to the order Acidimicrobiales and Actinomycetales were reported (Bacelar-Nicolauand Johnson, 1999; Blötheet al., 2008).

It's been possible to isolate actinobacteria from orders different to acidimicrobiales from tailings or mining concentrates (Matsubara and Hurtado, 2013; Schippers et al., 2002), founding genres such as Catellatospora (Lee $\boldsymbol{e t}$ al., 2000a), Saccharothrix (Lee et al., 2000b), Pseudonocardia (Lee et al., 2001), and Nocardiopsis metallicus(Schipperset al., 2002).

Bacterial leaching or Bioleaching is a process that implies the solubilization of metals using microorganisms and it's determined by the mineralogy and other factors. Bacterial cells can affect the dissolution of metals via the oxidation of iron or sulfur (Trujillo et al., 2012), the generation of organic acids (Schippers et al., 2014; Vera et al., 2013), or processes not yet determined (Schippers et al., 2014). The use of the actinobacteria Nocardiopsis metallicus has been demonstrated in the dissolution of metals of alkali silicates (Vera et al., 2013). The objective of our study was to investigate 24 strains of actinobacteria isolated from minerals from different mining areas of Peru to determine their taxonomic classification and physiological diversity. Likewise, it has been tried to determine the important characteristics for leaching processes and their capacity to grow in arsenopyrite since most of the strains come from arsenopyrite minerals.

\section{MATERIAL AND METHODS}

\section{Strains and growth medium}

Twenty-four strains of actinomycetes were used, which were isolated from minerals, tailings and concentrates from various mining areas of Peru (Table 1). A total of 13 isolates of arsenopyrite, 9 of pyrite, 1 of polymetallic sulphide and 1 of magnetite were used. In a previous study, physiological characteristics of 6 of the 24 strains were reported (Matsubara and Hurtado, 2013). To perform the tests, Casein-Starch medium (AAC)and Glycerol-Yeast Extract medium (XGAL)(Matsubara and Hurtado, 2013) and sometimes $10 \%$ dilutions of these media were used: AAC 1/10 and XGAL 1/10. ISP4 medium Agar-starch-mineral salts was also used (Shirling and Gottlieb, 1966).

\section{Morphological characterization}

Macromorphological characteristics were determined in each growth medium of the 5 media used, as aerial mycelium color, mycelium substrate, diffusible pigment production in the medium and texture of the morphological colonies of the strains were observed following the methods used in The International Streptomyces Project (ISP) (Shirling and Gottlieb, 1966). The cultures were incubated at $28^{\circ} \mathrm{C}$ and revised weekly, up to 30 days.

\section{Molecular analysis}

The 24 strains of actinobacteria were cultured in XGAL 1/10 broth. Genomic DNA was extracted from $1.5 \mathrm{~mL}$ of culture. Briefly, the bacteria were centrifuged and resuspended in lysis solution (1\% SDS, 1mM EDTA 10mM and TRIS-HCl, pH 8). Bacteria were lysed using Fast Prep FP 120 with $100 \mu \mathrm{m}$ Zirconium beads. The DNA was purified by a chloroform wash and precipitated with isopropanol. Genomic DNA was eluted in $10 \mathrm{mM}$ TRIS-HCl, pH 8 (Kumar et al., 2010; Kumar et al., 2013). The complete sequence of the 16S rRNA gene was amplified using primers 16S 8F (5'AGA GTT TGA TCM TGG CTC AG3') (Okibeet al., 2003) and 16S 1492R (5'GGT TAC CTT GTT ACG ACT T3') (Paramasivamet al., 2011). The amplified product size was approximately 1500 bp. The amplified product was sequenced in three overlapping segments using 6 primers. The sequences of the forward primers were: $16 \mathrm{~S} 8 \mathrm{~F}, 16 \mathrm{~S} 337 \mathrm{~F}\left(5^{\prime} \mathrm{GAC}\right.$ TCC TAC GGG AGG CWG CAG3') (Jaricet al., 2009) and 16S 785F (5'GGA TTA GAT ACC CTG GTA3')(Jaricet al., 2009). The reverse primers were: $16 \mathrm{~S}$ 
1492R, 16S 518R (5'GTA TTA CCG CGG CTG CTGG3') (Jaricet al., 2009), and 16S 907R (5'CCGTCA ATTCCT TTR AGT TT3') (Jaricet al., 2009). The sequences were assembled using the online program MERGER. The complete sequence result was evaluated in the online program BLASTn. The sequences with more than $99 \%$ identity were considered as identified isolate.

Table 1 Origin of Actinobacterias isolates

\begin{tabular}{|c|c|c|c|c|}
\hline Strain & Origin & pH & Zone & Reference \\
\hline Y16 & Pyrite tailing & 6.0 & Arequipa,Peru & Hurtado, 1984 \\
\hline YA4 & Pyrite tailing & 6.0 & Arequipa, Peru & Hurtado, 1984 \\
\hline K1A & Pyrite concentrate 1 & 1.8 & Arequipa, Peru & Hurtado, 1984 \\
\hline K1B & Pyrite concentrate 1 & 1.8 & Arequipa, Peru & Hurtado, 1984 \\
\hline K2 & Pyrite concentrate 1 & 1.8 & Arequipa, Peru & Hurtado, 1984 \\
\hline K4 & Pyrite concentrate 1 & 1.8 & Arequipa, Peru & Hurtado, 1984 \\
\hline AB5 & Pyrite concentrate 1 & 1.8 & Arequipa. Peru & Hurtado, 1984 \\
\hline AB7 & Pyrite concentrate 1 & 1.8 & Arequipa, Peru & Hurtado, 1984 \\
\hline 11-1 & Pyrite concentrate 2 & 4.0 & Arequipa, Peru & Hurtado, 1984 \\
\hline $\mathbf{X}$ & Magnetite mineral & 4.0 & Tacna, Peru & Hurtado, 2003 \\
\hline 21 & Polymetallic Sulfide mineral & 3.0 & Lima, Peru & Matsubara, 2013 \\
\hline C2 & Arsenopyrite tailing & 1.5 & Lima, Peru & Hurtado et al., 1990 \\
\hline Frep13 & Arsenopyrite tailing & 1.5 & Lima, Peru & Hurtado et al., 1990 \\
\hline Frep14 & Arsenopyrite tailing & 1.5 & Lima, Peru & Hurtado et al., 1990 \\
\hline Frep15 & Arsenopyrite tailing & 1.5 & Lima, Peru & Hurtado et al., 1990 \\
\hline F1 & Arsenopyrite tailing & 2.0 & Lima, Peru & Hurtado et al., 1990 \\
\hline $\mathbf{F}$ & Arsenopyrite tailing & 2.0 & Lima, Peru & Hurtado et al., 1990 \\
\hline E1 & Arsenopyrite tailing & 2.0 & Lima, Peru & Hurtado et al., 1990 \\
\hline Fe5 & Arsenopyrite tailing & 2.0 & Lima, Peru & Hurtado et al., 1990 \\
\hline $6 B$ & Arsenopyrite concentrate & 2.5 & Trujillo, Peru & Matsubara, 2013 \\
\hline $6 \mathrm{C}$ & Arsenopyrite concentrate & 2.5 & Trujillo, Peru & Matsubara, 2013 \\
\hline 6D & Arsenopyrite concentrate & 2.5 & Trujillo, Peru & Matsubara, 2013 \\
\hline $6 \mathbf{6 1}$ & Arsenopyrite concentrate & 2.5 & Trujillo, Peru & Hurtado, 2003 \\
\hline $6 \mathrm{E3}$ & Arsenopyrite concentrate & 2.5 & Trujillo, Peru & Hurtado, 2003 \\
\hline
\end{tabular}

\section{Physiological characterization}

The following characteristics were evaluated: 1 . growth at different $\mathrm{pH}(2,3.5,5$ and 7$)$ and different levels of salinity $(1.5,5,7$ and 10$) ; 2$. Growth and oxidation of ferrous sulfate $(1 \mathrm{~g} / \mathrm{L})$ at different $\mathrm{pH}(2,4$ and 7$)$ and; 3. Growth and oxidation of sodium thiosulfate $(1 \mathrm{~g} / \mathrm{L})$ at $\mathrm{pH} 4$ and $\mathrm{pH} 7$.

To perform all the tests the 24 strains were cultured in XGAL $1 / 10$ broth at $30^{\circ} \mathrm{C}$ for 07 days, and an inoculum with a density corresponding to $5 \times 10^{8} \mathrm{bact} / \mathrm{mL}$ was prepared. $0.5 \mathrm{~mL}$ of the inoculum was seeded into $10 \mathrm{~mL}$ XGAL 1/10 tubes. For the tests at different $\mathrm{pH}$, the XGAL $1 / 10$ was previously taken to the final $\mathrm{pH}$ by the addition of $\mathrm{H}_{2} \mathrm{SO}_{4} 1 \mathrm{~N}$. For the other tests, $\mathrm{NaCl}$, ferrous sulfate or sodium thiosulfate were added in the required concentrations. In the tubes with sodium thiosulphate, orange methyl was added as an indicator. All tests and controls were performed in duplicate. They were incubated at $30^{\circ} \mathrm{C}$ for up to 30 days.

The pellet formation was evaluated as growth indicator every 3 days, using a qualitative scale and,at the end of the test the purity of the culture was checked by microscopic observations and growth in solid media. The oxidation of ferrous ion was evaluated qualitatively by the formation of a red brick color that shows the formation of ferric ion. The oxidation of sodium thiosulfate was considered positive when there was a pink coloration by the turn of the indicator.

\section{Leaching of Arsenopyrite}

The following tests were performed: 1 . growth of 24 strains on 5\% arsenopyrite $(\mathrm{pH} 2$ and $\mathrm{pH} 7)$ and; 2 . Test of leaching of arsenopyrite. The arsenopyrite tail had the following composition: As $0.99 \%$ and Fe $5.45 \%$.

To perform the growth tests, the 24 strains were grown in AAC1/10 broth at $30^{\circ} \mathrm{C}$ for 7 days, and an inoculum with a density corresponding to $5 \times 10^{8} \mathrm{bact} / \mathrm{mL}$ was prepared. $0.5 \mathrm{~mL}$ of the inoculum was seeded in Falcon tubes with $30 \mathrm{~mL}$ of XGAL 1/10 medium and $1.5 \mathrm{~g}$ of arsenopyrite tail. For the tests at $\mathrm{pH} 2$ and $\mathrm{pH}$ 7, the solution was previously brought to the final $\mathrm{pH}$ by addition of $\mathrm{H}_{2} \mathrm{SO}_{4}$ $1 \mathrm{~N}$.Cultures were maintained at $28^{\circ} \mathrm{C}$ for 30 days. Growth was evaluated macroscopically and microscopically.

For the leaching tests, $25 \mathrm{~g}$ of sterile arsenopyrite tail and $500 \mathrm{ml}$ of medium at pH7 were placed in Erlenmeyer flasks. They were inoculated with $5 \mathrm{~mL}$ of cultures of strains $\mathrm{AB} 5$ and $\mathrm{E} 1$; and then shaken for 30 days at $28^{\circ} \mathrm{C}$. Control experiments were carried out in the same manner, but without inoculum and under sterile conditions. All tests were run in duplicate. Growth was evaluated periodically by microscopic and macroscopic means. The solution was filtered and the arsenic content in solution was determined in the filtrate by atomic absorption.

\section{RESULTS}

\section{Morphological characterization}

All strains were able to grow in solid and liquid medium of ISP4, AAC and XGAL. Three isolates were slow growing bacteria (more than 3 weeks). Sometimes, to obtain the growth in complete medium (XGAL or AAC), they had to be previously planted in dilute medium XGAL 1/10. Strains 11.1 and Fe5 formed colonies smaller than $1 \mathrm{~mm}$, unlike all of the others that form colonies of $5 \mathrm{~mm}$. The E1 strain has a red pigment in the colony; the 6C strain is dark brown in color and the Frep 13 and Frep 15 strains are light brown in color. All have aerial mycelium, most of them gray or white. Also, most produce diffusible green or orange pigments in the medium.

\section{Molecular analysis}

Analysis of the 16S rDNA gene sequence, with more than $99 \%$ identity, identified 23 isolates within the genus Streptomyces and one isolated within the genus Actinomadura (Table 2).

\section{Physiological characterization}

The strains more sensible to $\mathrm{NaCl}$ were $\mathrm{Fe} 5$ and 11.1 , which were able to grow only at $1.5 \% \mathrm{NaCl}$, and a total of 8 strains grew at $10 \% \mathrm{NaCl}$ (Figure $1 \mathrm{~A})$.

All strains showed capacity of growthat $\mathrm{pH} 5$ and $\mathrm{pH}$ 7, (Figure 1B). But not all of them oxidize iron (Figure $1 \mathrm{C}$ ). All results of growth and oxidation in XGAL $1 / 10+1 \mathrm{~g} / \mathrm{L}$ ferrous iron at different $\mathrm{pH}$ levels are shown in Figure 1.

Growth in the presence of sodium thiosulfate $1 \mathrm{~g} / \mathrm{Lat} \mathrm{pH} 7$ and 4 was observed in all strains, but no oxidation was obtained. 
Table 2 Identification of isolates from different mining areas of Peru based on $16 \mathrm{~S}$ rDNA gene sequencing.

\begin{tabular}{|c|c|}
\hline Strain & Identification \\
\hline Y16 & Streptomyces heilongjiangensi Y16 \\
\hline YA4 & Streptomyces albidoflavus YA4 \\
\hline K1A & Streptomyces variabilis $K 1 A$ \\
\hline K1B & Streptomyces thermocarboxydus $K 1 B$ \\
\hline $\mathbf{K} 2$ & Streptomyces sp. K2 \\
\hline K4 & Streptomyces matensis $K 4$ \\
\hline AB5 & Streptomyces variabilis AB5 \\
\hline AB7 & Streptomyces sp. AB7 \\
\hline 11-1 & Streptomyces ginglanensis 11-1 \\
\hline $\mathbf{X}$ & Streptomyces variabilis $X$ \\
\hline 21 & Streptomyces variabilis 21 \\
\hline $\mathbf{C 2}$ & Streptomyces sp.C2 \\
\hline Frep13 & Streptomyces champavatii Frep 13 \\
\hline Frep14 & Streptomyces heilongjiangensis Frep 14 \\
\hline Frep15 & Streptomyces peruviensis Frep 15 \\
\hline F1 & Streptomyces sp. F1 \\
\hline $\mathbf{F}$ & Streptomyces variabilis $F$ \\
\hline E1 & Streptomyces sp. E1 \\
\hline Fe5 & Actinomadura sp. Fe5 \\
\hline $6 B$ & Streptomyces heilongjiangensis $6 B$ \\
\hline 6C & Streptomyces sp. 6C \\
\hline 6D & Streptomyces sp. $6 D$ \\
\hline $6 \mathrm{E} 1$ & Streptomyces sp. 6E1 \\
\hline $6 \mathbf{E 3}$ & Streptomyces sp. $6 E 3$ \\
\hline
\end{tabular}

\section{Leaching of Arsenopyrite}

Of the 24 strains, only isolates E1 and AB5 were able to develop in arsenopyrite tailings at pH 7 (Table 3). None of the two strains was able to develop at $\mathrm{pH} 2$. The E1 strain formed circular aggregates, which showed the characteristic red color of the strain, they were in the solution and adhered to the wall of the flask. The AB5 strain grew to a lesser extent and formed small grey aggregates. The leached solutions ofE1 and AB5 showed an extraction of $19.1 \%$ and $15.5 \%$ of the arsenic present in the arsenopyrite tailings. The control showed an arsenic solubilization of $2.5 \%$.

\section{DISCUSSION}

All the 24 strains grew in the three medium used, showing different macroscopic morphology. In microscopic observations, aerial mycelium is observed with chains of spores typical of Streptomyces (Kämpferet al., 2015; Shirling and Gottlieb, 1966). The strain Fe5 presented morphology that correlates with the genus Actinomadura (Trujillo et al., 2012) and it was confirmed by molecular identification. The isolation of Streptomyces has been reported from uranium mines (Lorenz et al., 2007) and polish black shale ores (Suto et al., 2007). However, there is no a previous report of Actinomadura from mineral ores.

Streptomyces isolates do not show correlation by the characteristics of the origin, $\mathrm{pH}$ of the sample or the zone of collection. For example, the group formed by Y16, 6B and Frep14, identified as Streptomyces heilongjiangensi were collected from pyrite tailings, arsenopyrite concentrate and arsenopyrite tailings, at different $\mathrm{pHs}$ and in different regions of Peru (Arequipa, Lima and Trujillo). Results show the heterogeneity of species within the same collection area which would reflect the presence of a high diversity of strains within Streptomyces genus.

Many of the strains showed growth at $\mathrm{pH}$ levels lower than 5.The growth and oxidation tests of ferrous iron were performed in a diluted medium (Matsubara and Hurtado, 2013), with a final concentration of $0.05 \%$ glycerol and yeast extract of $0.02 \%$. This concentration of yeast extract is adequate so that heterotrophic acidophilic bacteria can grow without inhibition (Bacelar-Nicolau and Johnson, 1999). At low $\mathrm{pH}$, the molecules of organic acids in the growth medium are in their undissociated form and without charge. This kind of molecules can easily cross the cell membrane and act as decouples, producing toxic compounds (Koschorreck, 2008) and inhibiting the growth. It has been reported that different groups of Streptomyces have been isolated from acid soils with an average $\mathrm{pH}$ of 4.5 . The minimum $\mathrm{pH}$ with growth reported is 3 (Kämpfer et al., 2015; Vera et al., 2013; Willscher and Bosecker, 2003), however 16 of 23 isolated Streptomyces were able to grow at pH 2.

The peruvian isolates Streptomyces peruviensis (Frep15), Streptomyces ginglanensis (11.1) and Actinomadura sp. (Fe5) were considered as bacteria with slow or difficult growth because sometimes takes more than 20 days to obtain growth.
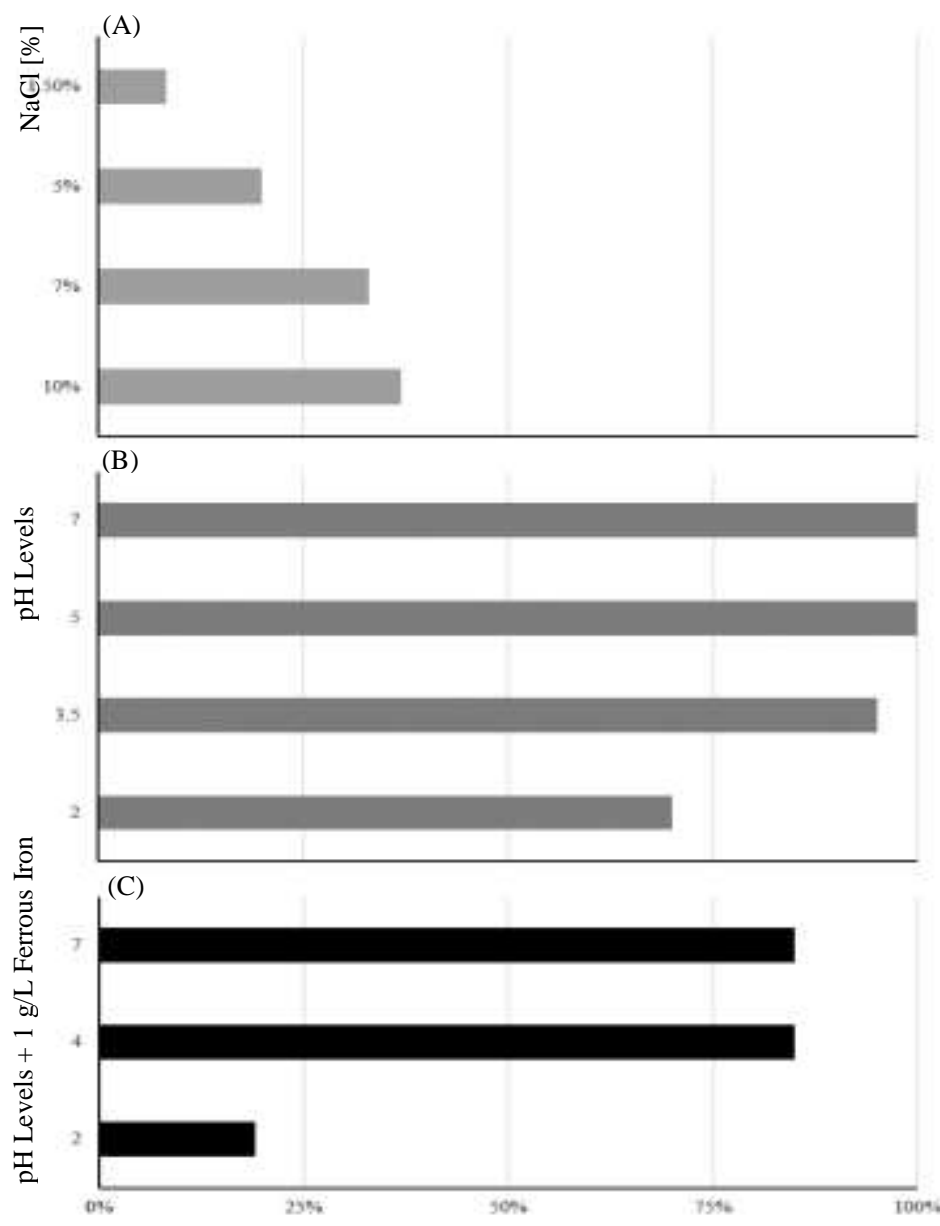

Growth Percentage of Strains

Figure 1 Growth Percentage of Strains at: A. Different levels of salinity; B. different $\mathrm{pH}$ levels; $\mathrm{C}$. different $\mathrm{pH}$ levels with $1 \mathrm{~g} / \mathrm{L}$ ferrous iron.

It has been demonstrated that all strains were incapable of oxidizing thiosulfate, althoughthey were able to growth in the presence ofthiosulfate $1 \mathrm{~g} / \mathrm{L}$. Many Streptomyces are able to use the thiosulfate pathway to produce cysteine (Wink et al., 2017) and also in some actinobacteria it has been demonstrated thiosulfate oxidation (Anandham et al., 2008).

Ferrous iron oxidation was observed mostly at $\mathrm{pH} 7$ and 4, and in less proportion at $\mathrm{pH}$ 2. The oxidation of ferrous iron, in all three $\mathrm{pH}$ levels, occurred after pellet formation, demonstrating that the iron oxidation it is not related to growth and suggesting that the strains of Streptomyces did not obtain energy for growth through the oxidation of ferrous iron. All 24 strains did not grow only with a source of iron (data not shown). The iron oxidation is widely present in bacteria and archea and in many cases it is not related to energy generation (Ilbert et al., 2013).Also, some of them catalize a dissimilatory oxidation of ferrous iron (Bryan and Jhonson, 2008; Ilbert et al., 2013)

Most of Streptomyces strains (17) were able to growth and oxidize iron at $\mathrm{pH} 7$ and 4 (Figure 2).Only Streptomyces sp. (strains C2, 6E1 and 6E3) and S.heilongjiangensis $6 B$ were able to growth and oxidize iron at $\mathrm{pH} 2$ and tolerate more than $5 \%$ sodium chloride. 


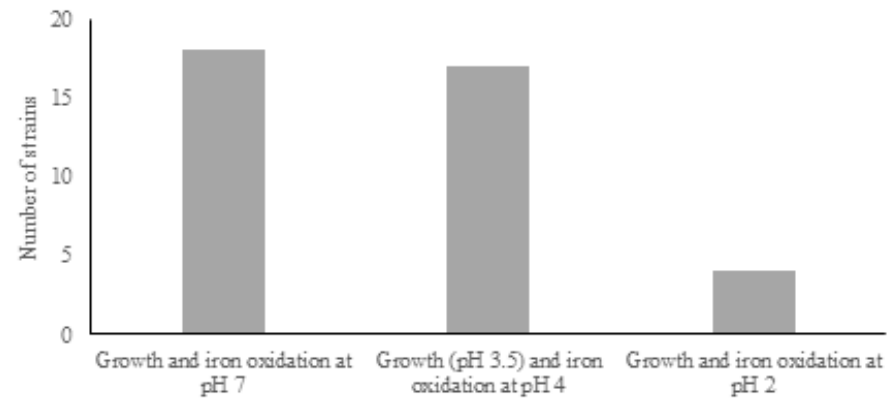

Figure 2 Number of strains showing growth and iron oxidation at different $\mathrm{pH}$ levels.

Tolerance was observed at different levels of salinity from $1.5 \%$ to $10 \% \mathrm{NaCl}$ This tolerance to high concentrations of sodium chloride is due to the fact that the osmotic pressure of the actinomycete cells is quite high, which allows survival of the actinomycetes in soils with high salinity (Bacelar-Nicolau and Johnson, 1999). Moreover, in the case of Streptomyces isolates would be related to the high concentration of metal ions present in the minerals from which they have been isolated.

Streptomyces sp. E1 showed the best extraction of arsenic from the arsenopyrite tailing, followed by Streptomyces variabilis AB5 (Table 3). Streptomyces sp. E1 has been isolated from arsenopyrite, which could explain its ability to oxidize arsenopyrite differently from Streptomyces variabilis AB5 which was isolated from pyrite. Both of them were able to oxidize iron at $\mathrm{pH} 4$ and higher. The leaching of arsenopyrite at acidic $\mathrm{pH}$ produces arsenic and iron in solution (Schippers et al., 2014), the arsenic is mostly found as As III or As V (Brierley and Brierley, 2013; Shirling and Gottlieb, 1966; Trujillo et al., 2012). At pH greater than 2.5 , the iron ion tends to form hydroxides and to precipitate, whereas As III remains in solution at higher $\mathrm{pH}$ (Bacelar-Nicolau and Johnson, 1999), for that reason arsenic is found in solution in the leaching test.

Table 3 Characteristics of strains able to leach arsenopyrite.

\begin{tabular}{|c|c|c|c|c|c|c|}
\hline \multirow{3}{*}{ Strain } & \multirow{2}{*}{\multicolumn{2}{|c|}{$\begin{array}{c}\text { Growth } \\
\text { pH }\end{array}$}} & \multicolumn{3}{|c|}{$\begin{array}{c}\text { Iron (II) } \\
\text { Oxidation }\end{array}$} & \multirow{3}{*}{$\begin{array}{c}\text { Growth } \\
\text { on } \mathrm{NaCl} \\
{[\%]}\end{array}$} \\
\hline & & & \multicolumn{3}{|c|}{ pH } & \\
\hline & 2 & 3.5 & 2 & 4 & 7 & \\
\hline Streptomyces variabilis AB5 & + & + & - & + & + & 10 \\
\hline Streptomyces sp. E1 & + & + & - & + & + & 10 \\
\hline
\end{tabular}

Legend: + , growth or oxidation; -, no growth or no oxidation

\section{CONCLUSION}

In this research, it has been possible to identify and characterize23 Streptomyces and 1 Actinomadura present in different peruvian mineral ores, being the first report of Actinomadura in minerals. Also, it has been demonstrated the capacity of Streptomyces sp. E1 and Streptomyces variabilis AB5 to grow and leach arsenopyrite. Streptomyces sp. (strains C2, 6E1 and 6E3) and S.heilongjiangensis $6 B$ were able to grow and oxidize iron at $\mathrm{pH} 2$, which it might allow to be used in acidic environments. All these results further expand the diversity of microorganisms that can be used as leaching agents in biohydrometallurgical and in other biotechnological applications.

Acknowledgements: This study was funded by the National Innovation Program for Competitiveness and Productivity (Innovate Perú) under contract 235-FincyTIA-2013. The authors express their gratitude to Mr. Arturo Berastain of BH Consultores for the samples of minerals provided, to Mr. Bryan Lucero for their collaboration in the molecular identification of strains and to Mrs. Yuri Puicon and Mrs. Sara Pancorbo for their technical support.

\section{REFERENCES}

Anandham, R., Indiragandhi, P., Madhaiyan, M., Ryu, K., Jee, H., Sa, T. (2008) Chemolithoautotrophic oxidation of thiosulfate and phylogenetic distribution of sulfur oxidation gene (soxB) in rhizobacteria isolated from crop plants. Res. Microbiol., 159(9-10), https://dx.doi.org/10.1016/j.resmic.2008.08.007
Bacelar-Nicolau, P., Johnson, D.B. (1999). Leaching of pyrite by acidophilic heterotrophic iron-oxidizing bacteria in pure and mixed cultures. Appl. Environ. Microbiol., 65(2), 585-590.

Baker, B.J., Banfield, J.F. (2003). Microbial communities in acid mine drainage. FEMS. Microbiol. Ecol., 44(2), 139-152.http://dx.doi.org/10.1016/S0168 6496(03)00028-X

Blöthe, M., Akob, D.M., Kostka, J.E., Göshel, K., Drake, H.L., Küsel, K. (2008). $\mathrm{pH}$ gradient-induced heterogeneity of $\mathrm{Fe}(\mathrm{III})$-reducing microorganismos in coa mining-associated lake sediments. Appl. Environ. Microbiol., 74(4), 10191029.http://dx.doi.org/10.1128/aem.01538-08

Brierley, C.L., Brierley, J.A. (2013). Progress in bioleaching: part B: applications of microbial processes by the minerals industries. Appl. Microbiol. Biotechnol. 97(17), 7543-7552.http://dx.doi.org/10.1007/s00253-013-5095-3

Bryan, C., Jhonson, D. (2008). Dissimilatory ferrous iron oxidation at low pH: a novel trait identified in the bacterial subclass Rubrobacteridae FEMSMicrobiol. Lett., 288(2), 149-155. https://dx.doi.org/10.1111/j.15746968.2008.01347.x

Ding, Y., Huang, Y., Ruan, J., Gao, Y. (2009). Selective isolation and diversity of acidophilic filamentous actinomycetes from acidic soils. Wei. Sheng. Wu. Xue. Bao., 49(6), 710-717.

Hurtado, J.E. (1984). Aislamiento, purificación y presencia de plasmidos en cepas nativas de Thiobacillus ferrooxidans. (Unpublished master's thesis). Universidad Peruana Cayetano Heredia, Lima, Perú.

Hurtado, J.E., Bauer, J.L., Maldonado, H., Cruz, E., Lazcano, E. (1990). Arsenic solubilization from Peruvian ores by Thiobacillus ferrooxidans. International Seminar on dump and underground bacterial leaching metals from ores, 86-95.

Hurtado, J.E. (2003). Variaciones bioquimicas y geneticas durante la seleccion de cepas de Acidithiobacillus ferrooxidans resistentes a arsenico lixiviado de concentrados refractarios de arsenopirita.(Unpublished doctoral dissertation). Universidad Peruana Cayetano Heredia, Lima, Perú.

Ilbert, M., Bonnefoy, V. (2013). Insight into the evolution of the iron oxidation pathways. Biochim. Biophys. Acta., 1827(2), 161-175. https://dx.doi.org/10.1016/j.bbabio.2012.10.001

Jaric, M., Segal, J., Silva-Herzog, E., Schneper, L., Mathee, K., Narasimhan, G. (2013). Better primer design for metagenomics applications by increasing $\begin{array}{lllll}\text { taxonomic distinguishability. BMC. } & \text { Proc., } & \text { 7(Suppl 7), S4 }\end{array}$ http://dx.doi.org/10.1186/1753-6561-7-s7-s4

Jones, R.M., Johnson, D.B. (2015). Acidithrix ferrooxidans gen. nov., sp. nov.: a filamentous and obligately heterotrophic, acidophilic member of the Actinobacteria that catalyzes disimilatory oxido-reduction of iron. Res. Microbiol., 166(2), 111-120.http://dx.doi.org/10.1016/j.resmic.2015.01.003

Kämpfer, P., Glaeser, S.P., Parkes, L., Van Keulen, G., Dyson, P. (2014). The Family Streptomycetaceae (Vol 42). Heidelberg:Springer Verlag.

Korechi, H., Blöte, M., Schippers, A. (2014). Microbial diversity at the moderate acidic stage in three different sulfidic mine tailings dumps generating acid mine $\begin{array}{llll}\text { drainage. } & \text { Res. } & \text { Microbiol., } & 165(9),\end{array}$ 718.http://dx.doi.org/10.1016/j.resmic.2014.08.007

Koschorreck, M. (2008). Microbial sulphate reduction at low pH. FEMS Microbiol. $\quad$ Ecol., $\quad$ 64(3), 329-342. https://dx.doi.org/10.1111/j.15746941.2008.00482.x

Kumar, V., Bharti, A., Gusain, O., Bisht, G. (2010). An improved method for isolation of genomic DNA from filamentous actinomycetes. J. Sci. Engg. \& Tech. Mgt., 2(2), 10-13.http://dx.doi.org/10.2478/s13545-013-0058-y

Kumar, P., Raja, R., Jundishapur, A.S. (2013). Novel Approaches of Genomic DNA Isolation for Identification of Cultivable Bacteria. J. J. Microbiol., 6(10), 2 4.http://dx.doi.org/10.5812/jjm.8339

Lee, S.D., Kang, S.O., Hah, Y.C. (2000). Catellatospora koreensis sp. nov., a novel actinomycete isolated from a gold-mine cave. Int. J. Syst. Evol. Microbiol., 50(3), 1103-1111.http://dx.doi.org/10.1099/00207713-50-3-1103

Lee, S.D., Kim, E.S., Roe, J.H., Kim, J.H., Kang, S.O., Hah, Y.C. (2000) Saccharothrix violacea sp. nov., isolated from a gold mine cave, and Saccharothrix albidocapillata comb. nov. Int. J. Syst. Evol. Microbiol., 50(3), 1315-1323.http://dx.doi.org/10.1099/00207713-50-3-1315

Lee, S.D., Kim, E.S., Min, K.L., Lee, W.Y., Kang, S.O., Hah, Y.C. (2001) Pseudonocardia kongjuensis sp. nov., isolated from a gold mine cave. Int. J. Syst. Evol. Microbiol., 51(4), 1505-1510.http://dx.doi.org/10.1099/00207713-51-4$\underline{1505}$

Lorenz, C., Merten, D., Haferburg, G.,Büchel, G. (2007).Laboratory investigations on the interactions of soil, water and microorganisms with manganese.Adv. Mat. Res., 20-21, 311-314. https://dx.doi.org/10.4028/www.scientific.net/amr.20-21.311

Matsubara, A., Hurtado, J.E. (2013). Isolation and characterization of actinomycetes from acidic cultures of ores and concentrates. Adv. Mater. Res., 825, 406-409.http://dx.doi.org/10.4028/www.scientific.net/amr.825.406 
Matsubara, A. (2013). Aislamiento y caracterización de actinomicetos a partir de muestras de minerales. (Unpublished thesis). Universidad Peruana Cayetano Heredia, Lima, Perú.

Mendez, M.O., Neilson, J.W., Maier, R.M. (2008). Characterization of a bacterial community in an abandoned semiarid lead-zinc mine tailings site. Appl. Environ. Microbiol., 74(12), 3899-3907.http://dx.doi.org/10.1128/aem.02883-07

Okibe, N., Gericke, M., Hallberg, K.B., Johnson, D.B. (2003). Enumeration and characterization of acidophilic microorganism isolated from a pilot plant stirredtank bioleaching operation. Appl. Environ. Microbiol., 69(4), 19361943.http://dx.doi.org/10.1128/aem.69.4.1936-1943.2003

Paramasivam, S., Ruban, P., Govindasamy, C. (2011). Histamine-Producing Bacteria (S-96) - A Molecular Approach. R.R.J.O.B.T., 1(3), 1-5.

Sanchez-Andrea, J., Rodriguez, N., Amils, R., Sanz, J.L. (2011). Microbial diversity in anaerobic sediments at Rio Tinto, a naturally acidic environment with a high heavy metal content. Appl. Environ. Microbiol., 77(17), 6085 6093.http://dx.doi.org/10.1128/aem.00654-11

Schippers, A., Bosecker, K., Willscher, S., Spröer, C., Schumann, P., Kroppenstedt, R.M. (2002). Nocardiopsis metallicus sp. nov., a metal-leaching actinomycete isolated from an alkaline slag dump. Int. J. Syst. Evol. Microbiol. 52(6), 2291-2295.http://dx.doi.org/10.1099/00207713-52-6-2291

Schippers, A., Breuker, A., Blazejak, A., Kock, D., Wright, T.L. (2010). The biogeochemistry and microbiology of sulfidic mine waste and bioleaching dumps and heaps and novel Fe(II).oxidizing bacteria. Hidrometallurgy, 104(3-4), 342350.http://dx.doi.org/10.1016/j.hydromet.2010.01.012

Schippers, A., Hedrich, S., Vasters, J., Drobe, M., Sand, W., Willscher, S. (2014) Biomining: metal recovery from ores with microorganisms. Adv. Biochem. Eng. Biotechnol., 141, 1-47. http://dx.doi.org/10.1007/10_2013_216
Shirling, E.B., Gottlieb, D. (1966). Methods for characterization of Streptomyces $\begin{array}{llll}\text { species. Int. J. Syst. Bacteriol., } & 16(3),\end{array}$ 340.http://dx.doi.org/10.1099/00207713-16-3-313

Suto, K., Bacosa, H., Inoue, C., Matsushima, E. (2007). Microbial Diversity in an Iron Oxidation Tank of an AMD Treatment Plant at Abandoned Sulphur Mine. Adv. Mat. Res., 20-21, 493-496. https://dx.doi.org/10.4028/www.scientific.net/amr.20-21.493

Trujillo, M.E., Goodfellow, M., Genus, III. (2012). Actinomadura (Vol. 5). Berlin: Springer-Verlag.

Urbieta, M.S., Toril, E.G., Aguilera, A., Giaveno, M.A., Donati, E. (2012). First prokaryotic biodiversity assessment using molecular techniques of an acidic river in Neuquén, Argentina. Microb. Ecol., $64 \quad$ (1), 91104.http://dx.doi.org/10.1007/s00248-011-9997-2

Vera, M., Schippers, A., Sand, W. (2013). Progress in bioleaching: fundamentals nd mechanisms of bacterial metal sulfide oxidation- part A. Appl. Microbiol. Biotechnol., 97(17), 7529-7541.http://dx.doi.org/10.1007/s00253-013-4954-2

Willscher, S., Bosecker, K. (2003). Studies on the leaching behaviour of heterotrophic microorganisms isolated from an alkaline slag dump Hydrometallurgy., $\quad$ 71(1-2), $\quad$ 257-264.http://dx.doi.org/10.1016/s0304386x(03)00164-6

Wink, J., Mohammadipanah, F., Hamedi, J. (2017). Biology and Biotechnology of Actinobacteria. (Vol. 1). Switzerland: Springer International Publishing. https://dx.doi.org/10.1007/978-3-319-60339-1

Zenova, G., Manucharov, N., Zvyagintsev, D. (2011). Extremophilic and Extremotolerant Actinomycetes in Different Soil Types. Eurasin. Soil. Sc., 44(4), 417-436.http://dx.doi.org/10.1134/s1064229311040132 